\title{
DIAMONDIFEROUS KIMBERLITES ON VICTORIA ISLAND, CANADA: A NORTHERN EXTENSION OF THE SLAVE CRATON
}

\author{
Mark Kolebaba ${ }^{1}$, George Read ${ }^{\mathbf{2}}$, Bernard Kahlert ${ }^{1}$ and Dave Kelsch ${ }^{1}$, \\ ${ }^{I}$ Diamonds North Resources Ltd, Canada; ${ }^{2}$ Canabrava Diamond Corporation, Canada
}

\section{INTRODUCTION}

Victoria Island, located in the Northwest Territories and Nunavut in the High Arctic of Canada (Figure 1) has been a diamond exploration target since 1993 when exploration companies recognized the possibility Archean age rocks beneath the eastern half of Victoria Island under thin Paleozoic carbonate cover. Much evidence has been collected through work since 1993 that suggests Victoria Island has the potential to become a world-class diamond-producing district.

Recent exploration efforts have identified kimberlites with high diamond counts and robust diamond size distributions trending toward large 1 to $2 \mathrm{~mm}$ stones from small kimberlite samples. Supportive mineral chemistry including major oxides and trace element analyses suggests a cool geotherm, presence of potential peridotitic diamond sources and a strong diamond bearing eclogite signature.

\section{GEOLOGY}

Archean rocks exist in the eastern half of Victoria Island. Paleozoic sediments including dolomite, minor limestone, sandstone and shale of the Arctic Platform have been preserved within postdepositional structural basins that are bounded by the Precambrian Minto, Wellington and Duke of York inliers. Granitic rocks within the Wellington Inlier, east of the Victoria Island kimberlite field, yielded a $\mathrm{U}-\mathrm{Pb}$ Zircon age of $2,601 \pm 3 \mathrm{Ma}$, confirming that the basement is a northern extension of the Archean Slave Province (LeCheminant, 1996). Granodiorite dated at $2.4 \mathrm{Ga}$ (Thorsteinsson and Tozer, 1962) in the southwest end of Hadley Bay intrudes metasediments that are by association Archean in age.

A broad syncline trending northeast across Victoria Island from Amundsen Gulf to Hadley Bay is composed of Precambrian strata of the Shaler Group. Approximately $2700 \mathrm{~m}$ of sandstone, siltstone, shale, limestone, dolomite, and gypsum underlie $300 \mathrm{~m}$ of basalt (Natkusiak Formation 723 Ma) and agglomerate which make up the Shaler Mountains that are intruded by gabbro sills. The lower sandstone and gabbro units of the Shaler Group are also found along the southern coast of Victoria Island, and as small inliers south of Washburn Lake.

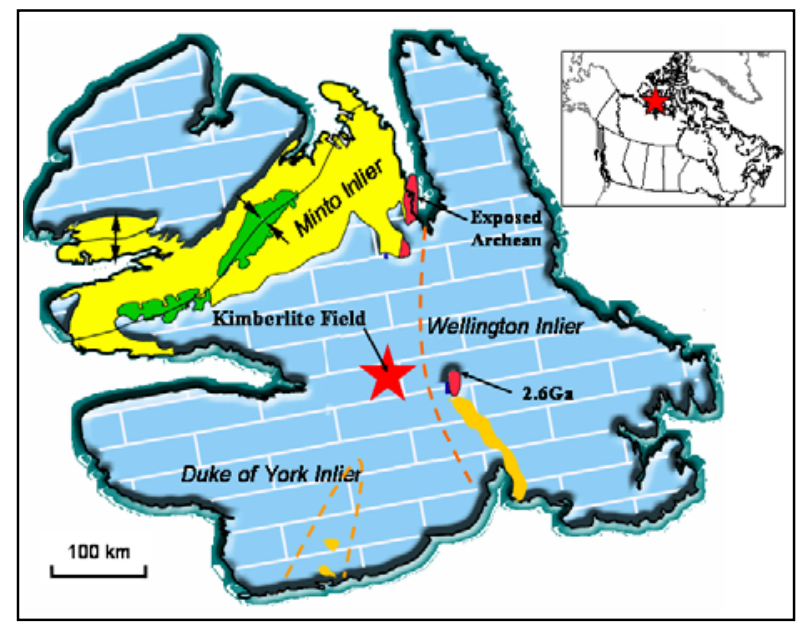

Figure 1: Location and geology map for Victoria Island.

Regional magnetics indicate the basement rocks have been intruded by NW-SE trending Mackenzie (1270 Ma) and Franklin (720 Ma) diabase dykes and a previously undocumented north-south trending diabase dyke system dated at $425 \mathrm{Ma}$ (Diamonds North Internal Report, 1999). Upper Cambrian to Lower Devonian sediments of the Arctic Platform covers most of the island. Their presence limits the emplacement age of kimberlites exposed beneath glacial overburden to less than $385 \mathrm{Ma}$. Victoria Island kimberlites have been dated at 256-286 Ma (Diamonds North Internal Report, 2000).

\section{KIMBERLITES}

On Victoria Island kimberlites occur as distinct pipes, dykes and as blows along several dyke structures. A semi-continuous string of kimberlite, known as the Galaxy Trend, has a strike length of 20 kilometers. Geophysics has been an effective tool in the discovery of kimberlite on Victoria Island. The kimberlites discovered to date display distinctive, 
discrete magnetic signatures, both magnetically positive and negative.

The non-magnetic nature of the $100 \mathrm{~m}$ to $200 \mathrm{~m}$ thick carbonate cover reduces the noisy magnetic signature of the Archean basement, allowing the younger kimberlites to stand out prominently with much higher frequency signatures. A typical example, the Snow Goose kimberlite, is illustrated in Figure 2.

The kimberlites of Victoria Island are typically rich in indicator minerals. Surficial sediment sampling is an effective means of exploration for these bodies. Indicator mineral grains include garnet, ilmenite, chromite and Cr-diopside.

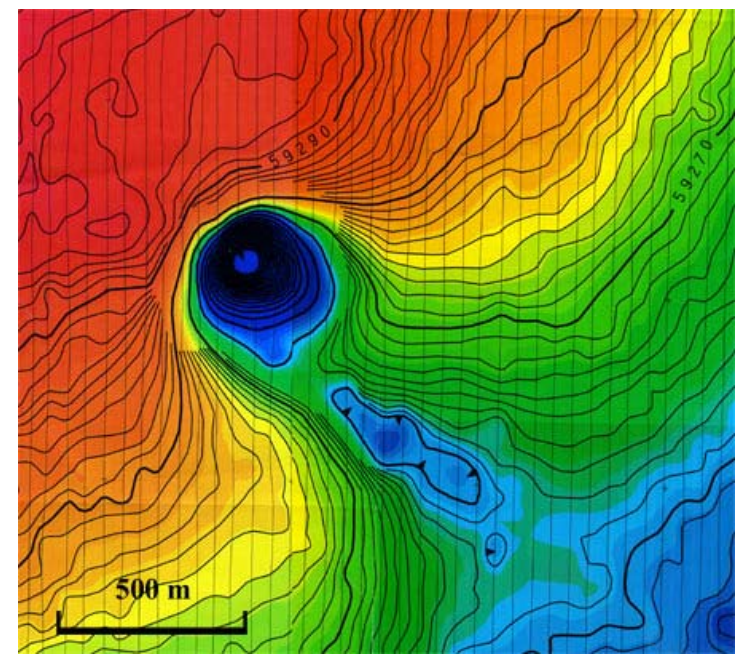

Figure 2: Magnetic signature over the Snow Goose kimberlite.

\section{THERMOBAROMETRY}

Recent trace element analyses for peridotitic garnets from the King Eider and Juno kimberlites indicate a cool geotherm of $38 \mathrm{~mW} / \mathrm{m}^{2}$ at the time of kimberlite emplacement for the central part of Victoria Island. The geotherm is constrained by the garnet P-T values with the lowest temperatures in the dataset, depicted in Figure 3. This geotherm is particularly important for Victoria Island as it indicates the thermal effects of the Mackenzie plume on the underlying lithospheric mantle were negligible. The $1270 \mathrm{Ma}$ Mackenzie event is much older than the alkalivolcanism responsible for Victoria Island kimberlite emplacement. The recovery of diamonds from these kimberlites negates detrimental thermal effects of the Mackenzie plume.

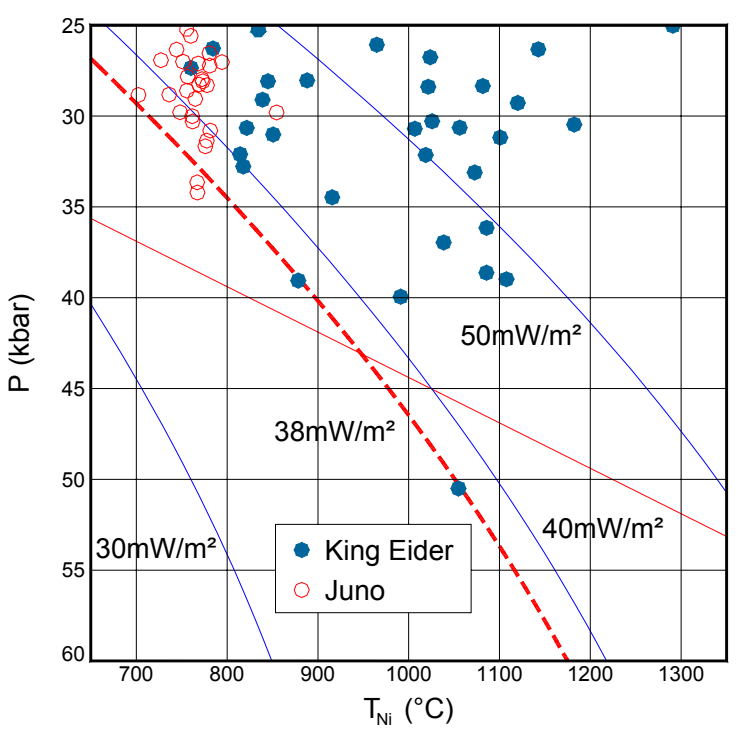

Figure 3: Geotherm of $38 \mathrm{~mW} / \mathrm{m}^{2}$ estimated by G. Read using data from King Eider and Juno Kimberlites. After Griffin, 1989.

Along a $38 \mathrm{~mW} / \mathrm{m}^{2}$ geotherm the diamond stability field is entered at $950^{\circ} \mathrm{C}$ and the base of the lithosphere, defined by the Yttrium edge, is at $1250^{\circ} \mathrm{C}$. Therefore, the mantle beneath Victoria Island has a diamond window between $950^{\circ} \mathrm{C}$ $(145 \mathrm{~km})$ and $1250^{\circ} \mathrm{C}(200 \mathrm{~km})$. For selected Victoria Island kimberlites, the garnet Ni-temperature histogram depicted in Figure 4 indicates the diamond window was well sampled as more than $80 \%$ of the garnets fall within the optimal temperature range.

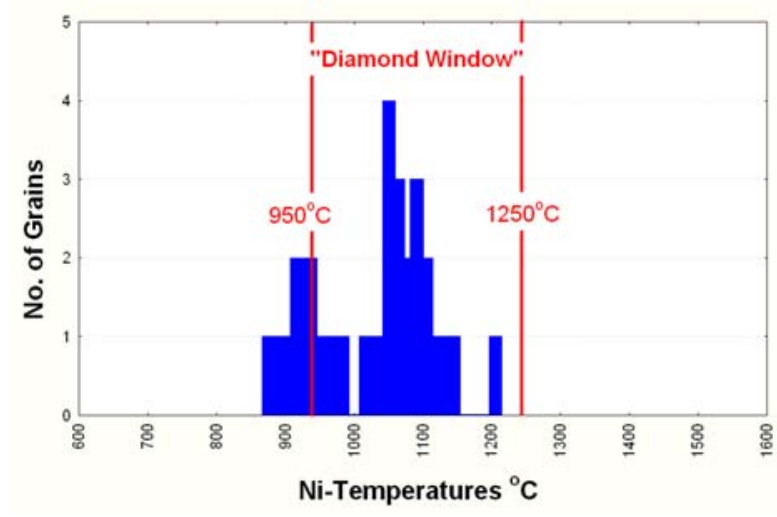

Figure 4: Histogram of garnet Ni-temperatures for King Eider Kimberlite. Ni-temperatures estimated using calculation by Canil 1999 .

\section{MANTLE COMPOSITION}

Mineral abundances and compositions for several kimberlites on Victoria Island indicate the lithospheric mantle underlying Victoria Island is 
comprised of both peridotitic and eclogitic parageneses. With respect to the peridotitic paragenesis, The $\mathrm{CaO}$ vs. $\mathrm{Cr}_{2} \mathrm{O}_{3}$ plot (Figure 5) demonstrates that the peridotitic paragenesis includes garnet harzburgite, and high $\mathrm{Cr}_{2} \mathrm{O}_{3}$ lherzolite $(>10$ wt $\% \mathrm{Cr}_{2} \mathrm{O}_{3}$. These peridotitic populations suggest that the host kimberlites have the potential to carry diamonds. A group of very subcalcic garnets between approximately $2 \%$ and $6 \% \mathrm{Cr}_{2} \mathrm{O}_{3}$ are also of interest.

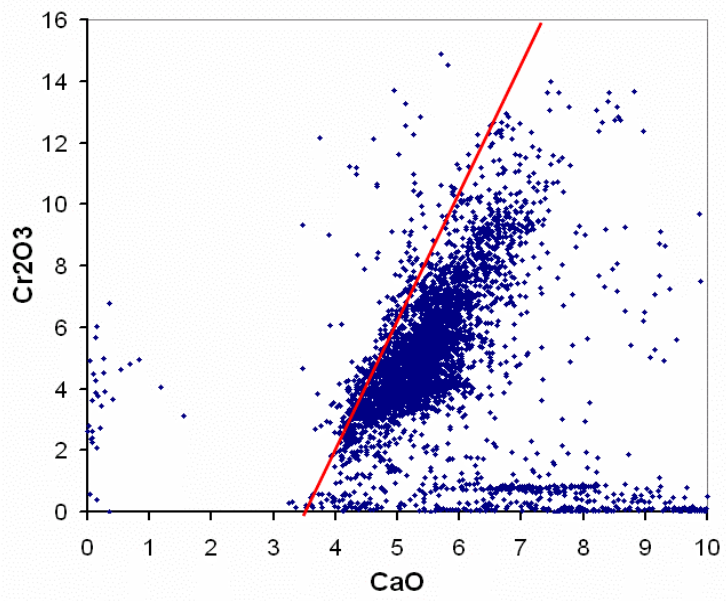

Figure 5: $\mathrm{CaO}$ vs. $\mathrm{Cr}_{2} \mathrm{O}_{3}$ plot of peridotitic garnets from several kimberlites on Victoria Island.

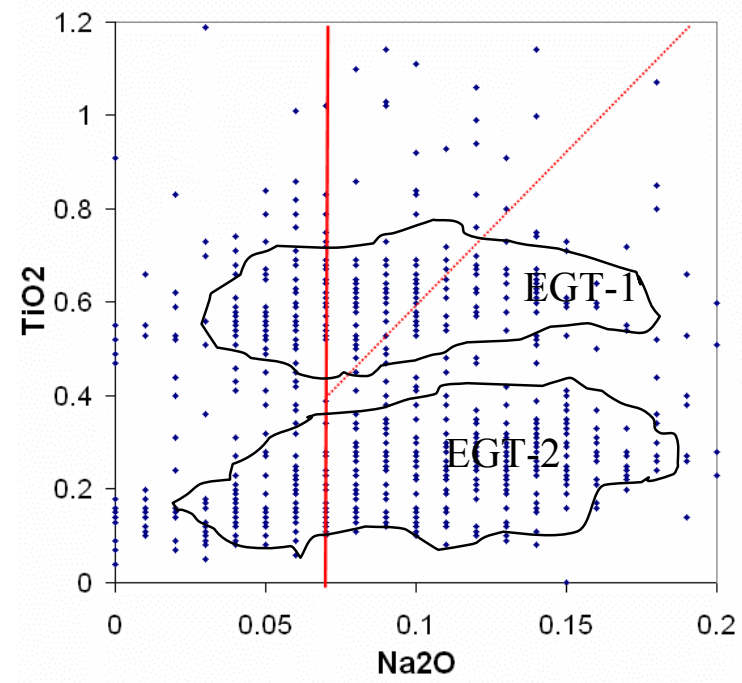

Figure 6: Diagram showing two populations of low $\mathrm{Cr}_{2} \mathrm{O}_{3}$ garnets.

The garnet population (Figure 5) contains low $\mathrm{Cr}_{2} \mathrm{O}_{3}$ garnets. These grains are further discriminated on a $\mathrm{Na}_{2} \mathrm{O}$ vs. $\mathrm{TiO}_{2}$ diagram (Figure 6), which indicates a high abundance of Group I eclogite garnets, and very few megacrystic compositions. The eclogitic garnets have been divided into two sub-groups, EGT-1 and EGT-2. The $\mathrm{Cr}_{2} \mathrm{O}_{3}$ contents of the two distinct garnet populations are illustrated by the peridotitic plot (Figure 5) and the histogram in Figure 7. Elevated $\mathrm{Cr}_{2} \mathrm{O}_{3}$ and higher $\mathrm{TiO}_{2}$ characterize the EGT-1 garnets. These garnets are possibly derived from websteritic source rocks. Similar websteritic garnet compositions are seen at the Victor and AT-56 kimberlites in the James Bay Lowlands of Ontario, Canada and are potential diamond source rocks for these kimberlites (Armstrong et al. 2003). EGT-2 garnets contain lower $\mathrm{Cr}_{2} \mathrm{O}_{3}$ and $\mathrm{TiO}_{2}$ and represent typical Group I eclogite compositions that may be associated with diamonds.

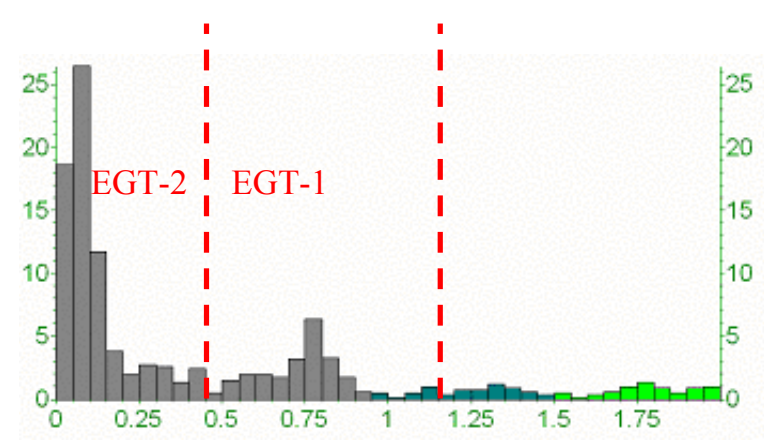

Figure 7: Histogram showing $\mathrm{Cr}_{2} \mathrm{O}_{3}$ content in Low $\mathrm{Cr}_{2} \mathrm{O}_{3}$ garnets - EGT-1 and EGT-2 groups.

\section{DIAMOND PRESERVATION}

Ilmenite grains recovered from Victoria Island kimberlites indicate that the rising kimberlite magma was under reducing conditions resulting in favourable diamond preservation. These data correspond with observations of diamond morphology. In general, many diamonds have distinct crystal faces, exhibiting little resorption, and are $85 \%$ to $95 \%$ preserved.

The ilmenite compositions from Victoria Island kimberlites are shown in different colours on Figure 8. All kimberlites are represented on the reduced side of the graph, and the distribution of and variations in ilmenite compositions may reflect mantle provenance. 


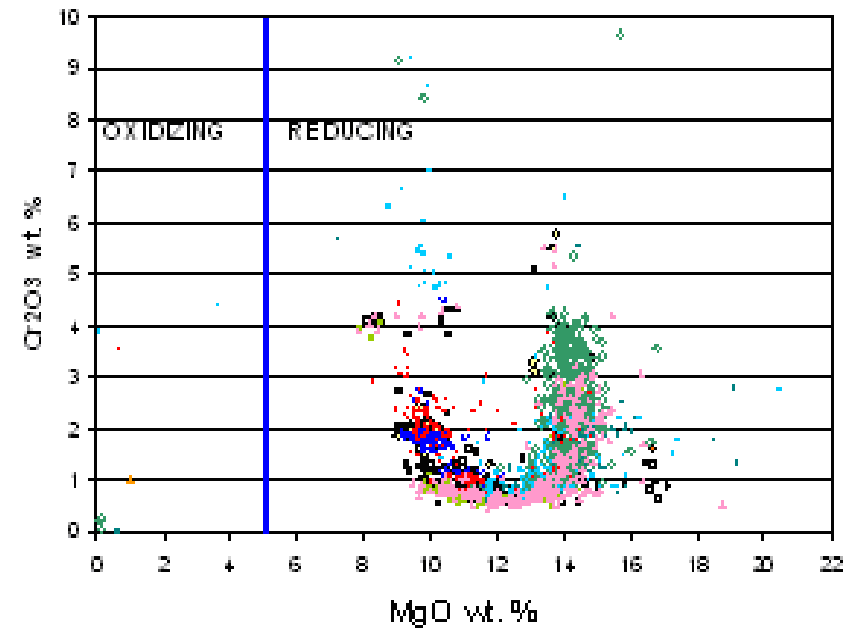

Figure 8: Kimberlitic ilmenite compositions for several kimberlites on Victoria Island.

\section{LITHOSPHERIC MODEL}

Kimberlite xenocryst paragenesis, kimberlite and basement geochronology and the presence of diamonds enable the development of a speculative lithospheric model for Victoria Island (figure 9). Archean age basement rocks underlying the Paleozic sediments suggest likely northward extension of the Slave Province. This is supported by a cool cratonic geotherm calculated from garnet Ni-thermometry. The proportion of garnets with temperatures in the diamond window suggests substantial sampling by kimberlites at depth between 145 and $200 \mathrm{~km}$. Kimberlite xenocryst composition suggests the sampling of peridotite (harzburgite, lherzolite and websterite) and eclogite at mantle depths within the diamond stability field. The abundance of eclogitic garnets present in the kimberlites suggests significant eclogitic component to the lithosphere beneath Victoria Island.

\section{ACKNOWLEDGEMENTS}

The Authors thank the following for their input: Michele Kolebaba (BHP-Billiton) and Lynn Grexton (Diamonds North) for diagrams.

\section{REFERENCES}

Armstrong K., Nowicki T., and Read G.H. 2003: Kimberlite AT-56 A mantle sample from the north central Superior Craton, Canada. Long Abstracts, $8^{\text {th }}$ International Kimberlite Conference, Victoria, Canada

Canil, D., 1999: The Ni-in garnet geothermometer: calibration at natural abundances. Contrib. Mineral Petrol 136:240-246

Griffin W.L., Ryan, C.G., Cousins, D.C., Sie, S.H., Suter, G.F., 1989: Ni in Cr-pyrope garnets: a new geothermometer. Contrib. Mineral. Petrol. 103: 199-202

Grutter H.S., Sweeney, R. J. 2000: Tests and constraints on single-grain Cr-pyrope barometer models: some initial results. Abstract: Geo-Canada 2000 Conference, Calgary, Canada.

LeCheminant, A.N., Rainbird, R.H. and Villeneuve, M.E. 1996: Precambrian geology of northern Wellington Inlier, Victoria Island, Northwest Territories: in Current Research 1996-C; Geological Survey of Canada, p. 110

Thorsteinsson, R. and Tozer, E.T. 1962: Banks, Victoria and Stefansson Islands, Arctic Archipelago; Geol. Survey of Canada Mem. 330, 85 p.

Contact: M.R. Kolebaba, 1550, 409 Granville St.

Vancouver, BC, Canada, V8W 3R7, E-mail:

mark.kolebaba@diamondsnorthresources.com

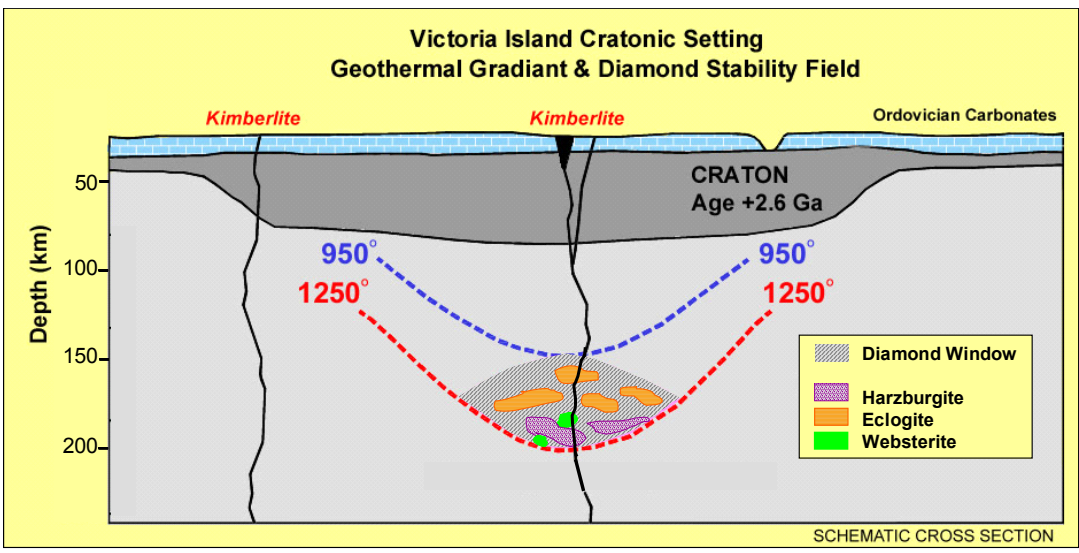

Figure 9: Speculative lithospheric model for Victoria Island. 